\title{
MEDIA IMAGES OF THE ARMED FORCES: A COMPARATIVE STUDY OF AMERICAN, INDIAN AND PAKISTANI PRESS Muhammad Riaz Raza ${ }^{1 *}$, Muhammad Usman Saeed ${ }^{2}$, Zafar Ali $^{3}$ \\ ${ }^{1 *}$ Assistant Professor, Media Studies, Bahria University, Islamabad Campus, Islamabad, Pakistan; ${ }^{2}$ Lecturer, Communication \& Media Studies, University of Management \& Technology, Sialkot Campus, Sialkot, Pakistan; ${ }^{3}$ Ph.D., Scholar, Communication \& Media Studies, University of Punjab, Lahore, Pakistan. \\ Email: ${ }^{1 *}$ mriaz.buic@bahria.edu.pk, ${ }^{2}$ usman841@yahoo.com, ${ }^{3}$ zafaralizfr@yahoo.com
}

\author{
Article History: Received on $22^{\text {nd }}$ May 2021, Revised on $9^{\text {th }}$ June 2021, Published on $14^{\text {th }}$ June 2021
}

\begin{abstract}
Purpose of the study: This study aims to analyze and compare the media images and coverage of three countries regarding their security forces. For this purpose, researchers have examined the media image of the American Army in the New York Times, the Indian Army in Indian Express, and the Pakistani Army in The Dawn.

Methodology: The researchers selected news stories of three sampled newspapers; New York Times, Indian Express, and The Dawn for one year from $1^{\text {st }}$ January 2018 to $31^{\text {st }}$ December 2018 purposively for the content analysis. Spearman correlations, central tendency, frames of the stories in terms of positive, negative, and neutral have been examined. The researchers have examined coverage patterns of security forces at the object, attribute, and network levels in the light of agenda-setting theory.
\end{abstract}

Main Findings: There are significant differences in the image of the armed forces. Indian Express covered the Indian army positively with the special emphasis on the success of the armed in internal military operations and the glorification of the military leadership. Similarly, New York Times covered the American Army favourably with a particular focus on external military operations for peace and security purposes. Whereas, The Dawn covered Pakistan Army differently.

Applications of this study: The study will be helpful and of great importance for media owners, media regulatory bodies, military establishments, foreign and international relations. The study will also be a significant contribution towards civil-military relationships in geostrategic locations of the sub-continent. Since these countries have been involved in war-on-terror in this region as far as peace and stability are concerned, the study will be a roadmap for the peacekeeping forces.

Novelty/Originality of this study: Few research studies have been witnessed so far on the media image of these countries. This study is new and different in nature as the military image of three different countries in terms of civilmilitary relationship has been measured on their mainstream media.

Keywords: Media Images, Security Forces' Images, New York Times, Indian Express, The Dawn, Network AgendaSetting.

\section{INTRODUCTION}

The media images of organizations and institutions have been considered a very important component for shaping public perception of a nation. To accomplish this task, the media is regarded as the primary tool in disseminating information to the public (Happer \& Philo, 2013). The media can place data and information to the people to take it without critical and interpretation (Nišić \& Plavšić, 2017). The intensity of media influence got amplified in cases where audiences got themselves emotionally associated with the issues on, which media reports e.g. reporting on war or conflicts $($ Tsfati \& Cohen, 2012). News reporting related to war and military conflicts is required to follow some sensitive and specific social responsibilities. It, sometimes, invokes public controversy over the military operations conducted due to unreasonable conflict reporting (Allan \& Zelizer, 2004).

In this era of conflicts and wars, the sphere of war is expanding from fighting on the ground to building counternarratives through media representation. It is imperative to study media narratives, and treatment of security forces to hit the root cause of insurgency, extremism, militancy, and terrorism. "Globally, the absolute number of war deaths has been declining since 1946. And yet, conflict and violence are currently on the rise.” (United Nations, 2020). Communication has become a central aspect of every field of life including military operations. Without winning public opinion, no war or military operation can get success (Scholtz, 1998). The importance and utilization of communication during war and conflict can be traced back historically like in world war II (Herf, 2006). However, with the rise of information tools and skills now it has become almost impossible to fight or win battles unless securing the information superhighways that link the world and community as well (Hussain, 2016). Raza et al. (2020) explored that few international news agencies have constructed a negative image of India and Pakistan through tweets. Pakistan is highly negatively portrayed in terms of conflicts and military operations while India is highly negatively portrayed regarding human rights violations. Pakistan Army has controlled media access to operational areas of Zarb-e-Azb in a war against militants and non-state actors (Javaid, 2015). The highly articulated means of communication developed by the modern world converted media to an instrument of war rather than a tool of information and awareness (Best et al., 2011). The physical defeat of the 
enemy at the battleground is not cherished unless the internal public opinion is shaped in favor of their forces (Payne, $\underline{2005})$.

The operations and acts conducted by the military forces cannot always be made public. People's perception about the armed forces got influenced by the media, where, images of the military are watched through television shows, movies, and the news and paid advertisements. In a study conducted on media coverage of Indo-Pak relations by $\underline{\text { Yousaf et al. }}$ (2018) that predominant coverage was based on war frames in mainstream media of both countries. Every country tends to construct a media image of its troops by disseminating information in the favour of its forces with regards to the services rendered to protect the country and its citizens (Oram, 1993). Public perception and attitudes are also essential in the case of working army personnel or retiring Army personnel to be transited back into a civilian society (Hines et al., 2015).

The global war on terror has been escalated after 9/11 and Pakistan became a leading country in this war with US and NATO forces (Khan, 2018). However, other media outlets of additional countries portray different images of armed forces and conflicts. National interest is considered as the prime objective for the media; hence reporting particularly in conflicts and wars, the media coverage becomes nationalistic and patriotic, resulting in compromising proper journalistic practices (Hussain, 2016). With the invention of modern techniques of communication and the invention of web 2.0 , every user has access to every kind of information shared and equally empowered to create, contribute and share content into the digital world through social media. Hence, now social media platforms have become a central arena of public discussion and debates resulting in a highlighted contribution of these platforms towards public opinion formation (Anstead \& O'Loughlin, 2014).

So where, traditional media is framing armed forces in a specific way by utilizing particular frames, social media also uses structures like fame and hero for armed forces (Parrott et al., 2018). Different studies conducted on the image and the portrayal of armed forces yielded different results regarding the image of their powers and strengths. Yang (2008), concludes that the American and the Chinese press used different frames for coverage of the Iraq war keeping in view their national interests. The content showed that the American armed forces were portrayed favorably by the American press while the Chinese press portrayed the military operations of the American armed forces negatively. Khan \& Pratt $\underline{(2020)}$ of the view that "since a decade, social media has been in the extensive use of Public Relations Wing of Pakistan Army to get and sustain support in the ongoing war on terrorism. The findings indicate that PR managers have used different strategic frames frequently in response to a fast-changing, evolving security situation in the region.

A study was conducted on the image of the armed forces in the British and American press, the researcher found that British personnel thought that media gave favorable coverage to the armed forces of the United Kingdom. On the other hand, in US media it is found a negative coverage (Ashcroft, 2012). Similarly, a study on the image of the Indian Army in the Indian local press has revealed that the Indian Army is portrayed unfavourably. The media in question has been covering such negative news on violations of human rights out of proportion for the Indian Army (Bali, 2015). Adegbola $\underline{(2020)}$ has conducted a study on the subscription habits of Nigerian journalists and found that "they were more inclined towards peace-oriented journalism than war-oriented journalism." Keeping in view the enormous importance of the media and armed forces in the present age of media-military relationship, this study seeks to highlight the coverage patterns and image of armed forces of three countries; India, Pakistan, and the United States in their elite press. It also aims to explore the different attributes of armed forces given by the media. The study is an effort to highlight the difference in media coverage related to the military operations conducted by the armed forces

\section{LITERATURE REVIEW}

\section{Pakistan Army and Media}

The media of Pakistan is regarded as one of the most vibrant media in the region. Since the liberalization of the Pakistani media in 2002, it has witnessed phenomenal expansion and growth. The free press and electronic media have significant effects on public perception, opinion, and attitudes of Pakistani society (Ashraf \& Islam, 2014). Pakistan is facing one of the biggest challenges of terrorism due to specific causes. Along with continuous efforts and operations conducted by armed forces, Pakistan launched a much-awaited Operation Zarb-e-Azb in June 2014. The process was meant to eradicate the menace of terrorism from the country. Yet, media reporting of the operation was not in unity with the stated policy of the government regarding counter-terrorism. It deviated from the boundaries set forth by the Constitution of the State and created a supportive environment for the propaganda of terrorists ( Khan \& Akhtar, 2016).

Similarly, the media coverage of the Lal-Masjid operation was not per the national interest, and there were multiple versions propagated by the media with different frames pre and post-conflict in 2007. The coverage of English dailies was quite different from Urdu dailies. The English press framed religious elements as 'evil other' and the government as 'elite us', whereas, Urdu dailies gave comparatively less content to the operation in their opinion pages ( $\underline{\text { Rahman \& Eijaz, }}$ 2014). In the case of the 'Abbottabad operation' in 2011, it is also evident that The Economist (Britain newsmagazine) and Time (American newsmagazine) adopted mainly war-oriented reporting than peace-oriented reporting. On the other hand, The Herald critically highlighted anti-war protests, pro-U.S. policies of Pakistani administration, and the causalities of the innocent civilians in Pakistan (Ishaq et al., 2018). 
After the 'Abbottabad operation' Pakistan Army launched military operations in tribal areas of Pakistan. The media did not portray a good image of these military operations. According to a survey conducted in Pakistan, the majority of the respondents were not in favor of the military action in troubled areas (Swat, North Waziristan) of Pakistan. It was also suggested by the majority of the respondents that a policy of dialogue and reconciliation should be opted to ease the tension. The results show that the Public Relations department of the armed forces needs to revise its PR strategies to make a positive and soft image of the Pakistan Army, which has been tarnished due to the military coups and proAmerican policies (Chaudhry \& Ali, 2012).

National media construct an image of the armed forces, which not only confine to the national boundaries but also be seen by the world media through the lens of the local press. Hence, the primary contributor toward image building of armed forces at international frontiers is the indigenous media of any country. Hussain et al. (2019) stated that despite the dominance of escalators coverage they explored some bits of reporting in the peace orientation rather than conflict orientation. Due to specific world events and terrorist activities, Pakistan remains among the countries with insecurity, conflict, and terrorism; hence national and international media image of Pakistan remains associated with negative connotations. Although this is not as true as portrayed by the media as the objective reality may have considerable differences from the fact presented by the media, because, the media are capable of framing a news story by creating a pseudo environment distant from the truth (Yousaf, 2015). A study conducted by Awobamise et al. (2020) explaining that media transformation from war orientation news to peace orientation news has taken ten years from 2007 to 2017. As far as the international media coverage is concerned, it depends on several factors like foreign relations, economic relations, investment, and national interest. A study found that Associated Press and Xinhua covered news related to Pakistan differently, particularly in addressing the issues like terrorism threat, the economic consequences, and international relations. The study concluded that information related to a particular country and event is framed to fulfill specific vested interests of global politics and to promote a particular ideology (Yousaf, 2015).

\section{Agenda-Setting of Media and Public Perception}

The role of mass media in the presentation of socio-political issues and objects and its perception among the public have been central among the agenda-setting scholars for last the five decades, starting from the ground-breaking Chappell Hill study in 1968 (Baran \& Davis, 2010; Graber \& Smith, 2005; McQuail, 2010). The traditional or first level of agendasetting studied agenda as a set of objects and issues (Lee \& Hahn, 2014; Sheafer \& Weimann, 2005; Walgrave et al., 2008). The objects are public issues, but they could be other items or topics, such as the image of organizations, institutions, and state actors (McCombs, 2005). Later on, this scholarship turned the focus from object agenda to attribute agenda. In other words, from the first level to the second level of agenda-setting (Rill \& Davis, 2008; Seltzer \& Dittmore, 2009; Walgrave et al., 2008; Wirth et al., 2010; Zhang \& Meadows III, 2012). For each object on the agenda, there is an agenda of attributes or specific characteristics of an issue or organization that influences our understanding of the object (McCombs, 2005). According to attribute level agenda-setting, the media not just provides significant issues to the public for discussion, but also associates specific characteristics with that issue to influence public perception.

For few decades, the interpretative style of journalism has been practicing by journalists all over the world (Prager \& Hameleers, 2021). Many scholars realize the media can be a weapon of war. The military needs to control the information it, is of utmost importance for the security of operation. On the other hand, the media also need the military for selling their news products. Therefore, the relationships between the military and the media are interdependent (Ramić, 2015). The Pentagon has been investing in Hollywood productions for building a favorable public perception for the armed forces (Powell, 2014). It is also argued and a public debate that "the media coverage during the Vietnam War significantly contributed to American public opinion." (Hadyniak, 2015). Later on, the Bush administration used US media extensively to project the military achievements in the Middle East (Le, 2016). In a study conducted by Manzoor et al. (2021) on the patterns of print media agendas in the context of war-on-terror in Pakistan, and it was concluded that "terrorism" was an extensively used word in two leading US newspapers.

Daud (2020) says on coverage of Afghan news in Western media that "the Western media chiefly covered violencerelated news and shape a false image of the country." A recent development in Agenda-Setting research is Network Agenda-Setting Model and its placement in the media-effects theories, proposed by Guo (2012). This model asserts that "the salience of the network relationships among objects and/or attributes can transfer from media to the public in addition to the rank-order salience". This expanded perspective on the bundling of objects and attributes has been termed as the third level of agenda-setting (Cheng \& Chan, 2015; Guo, 2012; Guo et al., 2012; Vargo et al., 2014; Vu et al., 2014). Christian et al. (2020) stated that this is called high time for proper use of social media in conflicts and crises, which develops such methods against the misuse of technology. Datsko (2020) claimed that online media funded by the Russian state indeed does perform as a propaganda machine.

Moreover, an important domain of agenda-setting research is intermedia agenda-setting. The Intermedia agenda-setting refers to one medium's agenda-setting impact on other media's agenda (McCombes et al., 2006). Simply, intermedia agenda-setting can be thought of as "transfer of issue salience" from one media to the other media". The studies found evidence of the intermedia agenda-setting on both object level (Heim, 2010; Vliegenthart \& Walgrave, 2008) and attribute level (McCombes et al., 2006). It is also evident on a network or third level of agenda-setting (Vu et al., 2014). Here in this study, the researchers argue that the armed forces of Pakistan for The Dawn are the same as the American 
Armed forces to the New York Times and Indian Armed Forces to the Indian Express. Therefore, we attempt to link the intermedia agenda-setting in cross-national perspectives. The present study also takes roots from object level, attribute level, and network-level agenda-setting to study and compare the media agenda towards armed forces in cross-national perspectives.

Keeping in view the literature available on the media image of armed forces along with the theoretical support of the intermedia agenda-setting at the network level, the researchers formulated two research questions and three hypotheses.

RQ1: To what extent armed forces are covered by American, Indian, and Pakistani Press?

RQ2: Which attributes are associated with armed forces in coverage of American, Indian, and Pakistani Press?

H1: There would be no differences in the tone of American, Indian, and Pakistani press about their armed forces.

H2: There would be a significant correlation among the attributes level agenda of American, Indian and Pakistani press about their armed forces.

H3: There would be a significant correlation among the network-level agenda of American, Indian, and Pakistani press about their armed forces.

\section{METHODOLOGY}

In the present study, the researchers used 'social-network' analysis to study the image of the armed forces in the American, Indian and Pakistani press. 'Social-network' analysis is an approach to identify and study the relationships between different elements, including objects, attributes, and characteristics (Butts, 2008; De Nooy et al., 2011; Marin \& Wellman, 2011; Wasserman \& Faust, 1994). Its applicability in the scholarship of network agenda-setting was found quite useful (Guo, 2012; Guo et al., 2012; Vargo et al., 2014; Vu et al., 2014). Therefore, the researchers have also used this approach in this study.

Firstly, researchers performed content analysis. The universe of the study was American, Indian, and Pakistani elite press. The researchers have selected three newspapers as a sample, one from each country namely Daily Dawn from Pakistan, New York Times from the USA, and Indian Express from India. The researchers accessed these newspapers online and selected stories related to armed forces for the period of the year 2018. The researchers decided to select news stories mentioning: U.S. Army, American Army, and Central Intelligence Agency (CIA) from New York Times (N=108); Pakistan Army, Pakistan Army, Inter-Services Intelligence from The Dawn (N=262) and Indian Army, Border Security Force (BSF), Research and Analysis Wing (RAW) from Indian Express (N=294). All the news stories were retrieved from online editions of these newspapers during January 2019.

The coding categories were inductively made by conducting a pilot study on 30 news stories. The researchers created sixteen types, including objects and attributes related to armed forces. These were; External Affairs / Conflict, CivilMilitary Relations, Military Operations, Peace \& Security, Military, leadership / Personnel, Win/ Success, Loss / Failure, Human Rights Violations, Defence Aid/Budget, Accountability, Terrorism Threat, The Public Welfare, Dominance, Internal Affairs, Glorification, and Social \& Cultural. For network coding, the researchers coded the co-occurrence of two elements (Annexure - I: Coding Categories). For this extensive coding process, the researchers trained three coders for three days. These coders were graduates in Mass Communication, and their medium of instruction was English. Inter-coder reliability was attained at 0.79 . Moreover, the tone of the news stories and attributes was coded from highly negative to highly positive (1-5). Lastly, researchers used descriptive statistics, ANOVA, Chi-square, spearman correlations, and degree centrality measures to find out and compare the media image of American, Indian, and Pakistani armed forces.

\section{RESULTS AND DISCUSSION}

Frequency of News Stories Published in Newspapers:

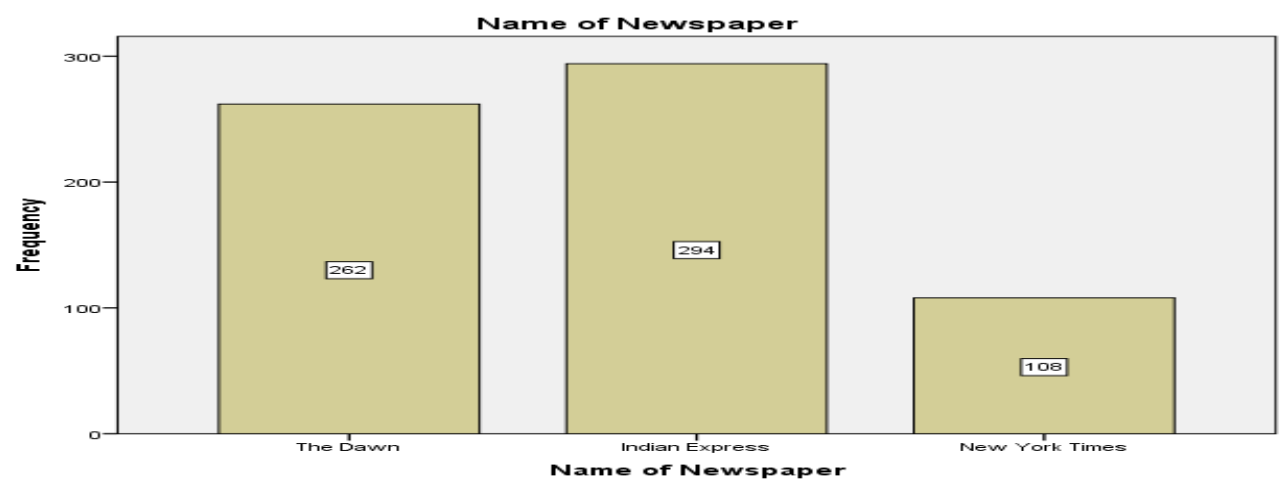

Figure 1: News Stories about Armed Forces in The Dawn, Indian Express, and New York Times 
Source: Author's calculations based on the news stories retrieved from online editions of these newspapers

Figure 1 indicates a significant difference in the news coverage of armed forces by the American, Indian and Pakistani press. India and Pakistan are almost giving high coverage to armed forces. However, American media is not giving more content to their armed forces. Hence, these findings provide an answer to RQ1 that the Pakistani and Indian press gave more attention and content to armed forces than the American press. In this way, it shows that in developing and underdeveloped countries the coverage of the Army is still significant in the news media. Moreover, American media is more democratic than Indian and the Pakistani media, this may be a factor that American media is more democratic oriented, therefore, it does not much focus on the news coverage of armed forces. Iftikhar \& Shafiq (2019) argued that "the public was not informed properly about the Iraq war similarly the Bush administration tried to propagate about the war against terrorism. The media coverage and the incident of 9/11 divided the views and initiated different debates across the world." One of the reasons for not informing the public properly was the alignment of mainstream media's editorial policy with the decisions of the government.

The Tone of the News Stories:

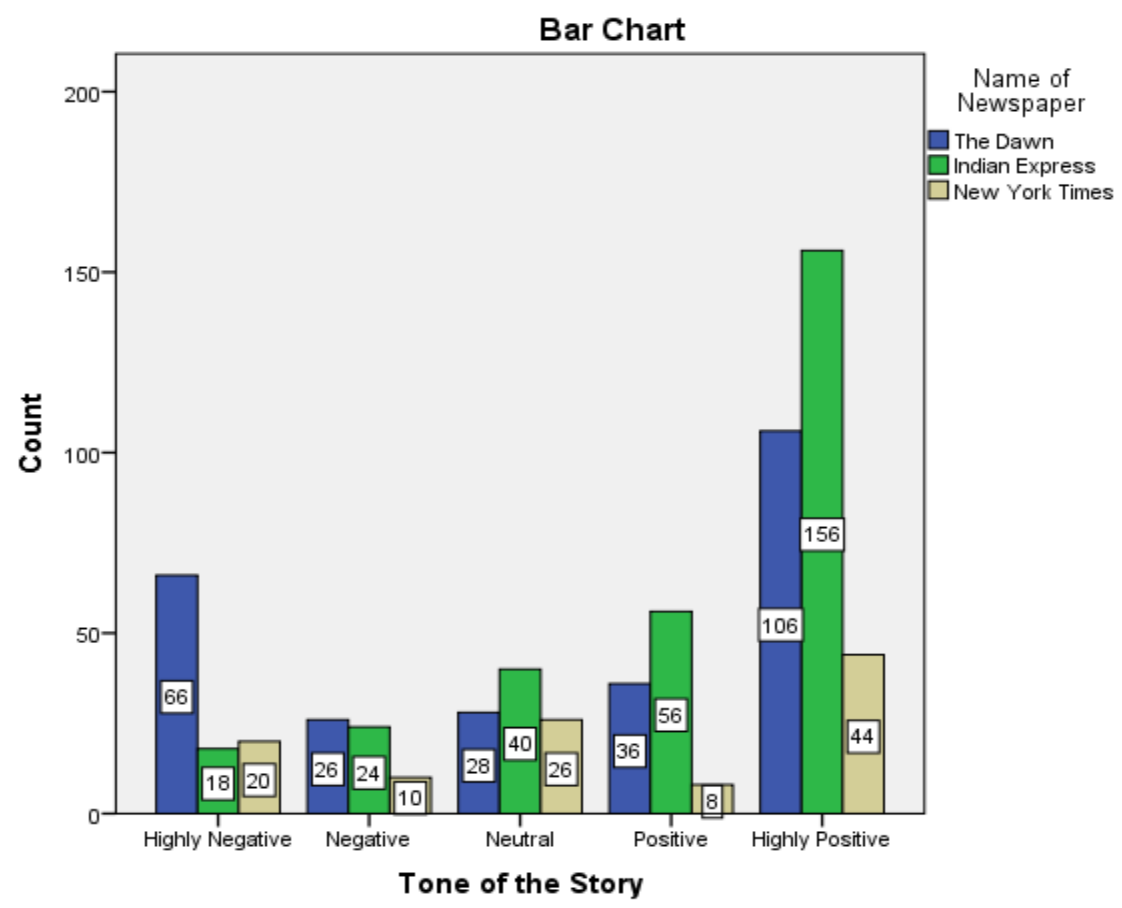

Figure 2: The Tone of the News Stories Armed Forces in The Dawn, Indian Express, and New York Times

Source: Author's calculations based on the news stories retrieved from online editions of these newspapers

Table 1: Mean Differences of the Tone of The Dawn, Indian Express and NY Times towards Armed Forces

\begin{tabular}{|c|c|c|c|c|c|c|c|}
\hline & \multirow[t]{2}{*}{$\mathbf{N}$} & \multirow[t]{2}{*}{ Mean } & \multirow[t]{2}{*}{ SD } & \multirow[t]{2}{*}{ Std. Error } & \multicolumn{3}{|c|}{ 95\% Confidence Interval for Mean } \\
\hline & & & & & Lower Bound & Upper Bound & \\
\hline The Dawn & 262 & 3.3435 & 1.659 & .10255 & 3.1416 & 3.5454 & $\begin{array}{l}F=17.67 \\
\mathrm{Sig}=0.000\end{array}$ \\
\hline $\begin{array}{l}\text { Indian } \\
\text { Express }\end{array}$ & 294 & 4.0476 & 1.243 & .07254 & 3.9048 & 4.1904 & \\
\hline $\begin{array}{ll}\text { New } & \text { York } \\
\text { Times } & \\
\end{array}$ & 108 & 3.4259 & 1.541 & .14838 & 3.1318 & 3.7201 & \\
\hline Total & 664 & 3.6687 & 1.505 & .05843 & 3.5539 & 3.7834 & \\
\hline
\end{tabular}

Source: Author's calculations based on the news stories retrieved from online editions of these newspapers

Figure 2 illustrated that although all three newspapers are giving more favorable coverage to their armed forces. However, The Dawn is also presenting a negative image of the Pakistan Army. Furthermore, Table 1 shows that Indian Express gives more favorable coverage to the Indian Army as compared to the American and Pakistani press coverage of the Armed forces. In this way, the findings do not find support for the confirmation of H1 that there would be no significant differences in the tone and style of American, Indian, and Pakistani press towards their armed forces. The researcher finds that there are substantial differences in the tone of The Dawn, Indian Express, and New York Times about the Pakistan Army, the Indian Army, and the American Army, respectively. Interestingly, the Pakistani media tone 
is almost neutral about armed forces. The other two newspapers are favorable towards their armed forces. For few decades, the interpretative style of journalism has been practicing by journalists all over the world (Prager \& Hameleers, 2021). The researchers have seen in recent decades that media sets agenda to defend and safeguard their country's interests instead to affiliate the truth and reality and to materialize particular narrative, the role of interpretative journalists has remained significant. Slanting the news has an impact on audiences in making an opinion on the national issues.

Table 2: Frequency of Army Attributes in News Stories of The Dawn, Indian Express, and New York Times

\begin{tabular}{|c|c|c|c|c|c|c|}
\hline & \multicolumn{6}{|c|}{ Frequency of Attributes } \\
\hline & \multicolumn{2}{|l|}{ Dawn } & \multicolumn{2}{|c|}{ Indian Express } & \multicolumn{2}{|l|}{ NY Times } \\
\hline & Frequency & Tone $(\mathrm{M})$ & Frequency & Tone (M) & Frequency & Tone $(\mathrm{M})$ \\
\hline External Affairs / Conflict & 60 & 4.07 & 60 & 4.2 & 48 & 3.16 \\
\hline Civil-Military relations & 112 & 2.48 & 32 & 3.56 & 34 & 3.94 \\
\hline Military Operations & 4 & 5 & 102 & 3.96 & 40 & 3.15 \\
\hline Peace \& Security & 70 & 4.57 & 88 & 4.31 & 30 & 4.53 \\
\hline $\begin{array}{lll}\text { Military leadership } \\
\text { Personnel }\end{array}$ & 86 & 3.6 & 92 & 4.32 & 32 & 2.93 \\
\hline Win/ Success & 54 & 4.7 & 102 & 4.8 & 24 & 4.75 \\
\hline Loss / Failure & 8 & 3.25 & 36 & 2.33 & 8 & 2.25 \\
\hline Human Rights Violations & 14 & 2.28 & 28 & 2 & 28 & 2.07 \\
\hline Defence Aid/ Budget & 12 & 3 & 30 & 3.67 & 22 & 3.36 \\
\hline Accountability & 66 & 1.24 & 10 & 1.6 & 22 & 1.72 \\
\hline Terrorism Threat & 28 & 4.21 & 40 & 3.8 & 24 & 3.75 \\
\hline Public Welfare & 28 & 4.57 & 10 & 5 & 6 & 5 \\
\hline Dominance & 50 & 1.44 & 10 & 3.8 & 0 & 3.42 \\
\hline Internal Affairs & 82 & 3.1 & 128 & 4.1 & 26 & 3 \\
\hline Glorification & 68 & 4.67 & 80 & 4.8 & 16 & 4.75 \\
\hline Social \& Cultural & 2 & 5 & 2 & 5 & 2 & 5 \\
\hline
\end{tabular}

Source: Author's calculations based on the news stories retrieved from online editions of these newspapers

Table 2 shows that the Pakistani press mainly focused on civil-military relations (negatively), internal affairs (neutral), military leadership (positively), and peace \& security issues (positively). Inter-Services Public Relations, Pakistan has rejected all the rumors regarding any political suggestion, alliance, or backdoor channels with Pakistan Democratic Movement (Dawn, 2021). On the other side, Indian Express primarily focused on military operations (positively), internal affairs of India (positively), and the success of the Indian Army (highly positive). The military leadership and glorification are also high in a positive direction by Indian Express. On the other side, New York Times chiefly focused on external affairs (neutral), military operations (neutral), and civil-military relations (positively) of the American Army. In this way, the findings provide an answer to RQ2.

Table 3: Correlations among the attribute of Armed Forces in The Dawn, Indian Express, and New York Times

\begin{tabular}{lllll}
\hline Correlations & \multicolumn{3}{c}{} \\
\hline \multirow{2}{*}{ Spearman's rho } & \multicolumn{5}{c}{ The Dawn } & Indian Express & New York Times \\
\cline { 2 - 5 } & The Dawn & 1.000 & .388 & .397 \\
\cline { 2 - 5 } & Indian Express & .388 & 1.000 & $.611^{*}$ \\
\cline { 2 - 5 } & New York Times & .397 & $.611^{*}$ & 1.000 \\
\hline *. Correlation is significant at the 0.05 level (2-tailed). & \\
\hline
\end{tabular}

Source: Author's calculations based on the news stories retrieved from online editions of these newspapers

Further, Table 3 shows that The Dawn attribute level agenda about armed forces is different from other two newspapers; Indian Express $(\mathrm{r}=0.38, \mathrm{p}=0.14)$ and New York Times $(\mathrm{r}=0.40, \mathrm{p}=0.12)$. On the other side, Indian Express and New York Times attribute level agenda has a significant correlation with one another $(\mathrm{r}=0.611, \mathrm{p}=0.01)$. Hence, the findings do not support our $\mathrm{H} 2$ that "there would be a significant correlation among the attributes level agenda of American, Indian and Pakistani press about their armed forces". The researchers found that the intermedia agenda about the same institution of different countries vary from country to country.

Figure 3 illustrates that The Dawn strongly linked the Pakistan Army with civil-military regards and internal affairs of Pakistan. In civil-military relations, it stressed the dominance of the Army and its accountability. Moreover, the newspaper also glorifies the military leadership and the military success or sacrifices for peace and security. "The media continues to play a central role in directing what information the public attends to, how it is presented, and with what they associate that information" (Stern et al., 2018). 
Network Image of Pakistan Army in News Stories of The Dawn

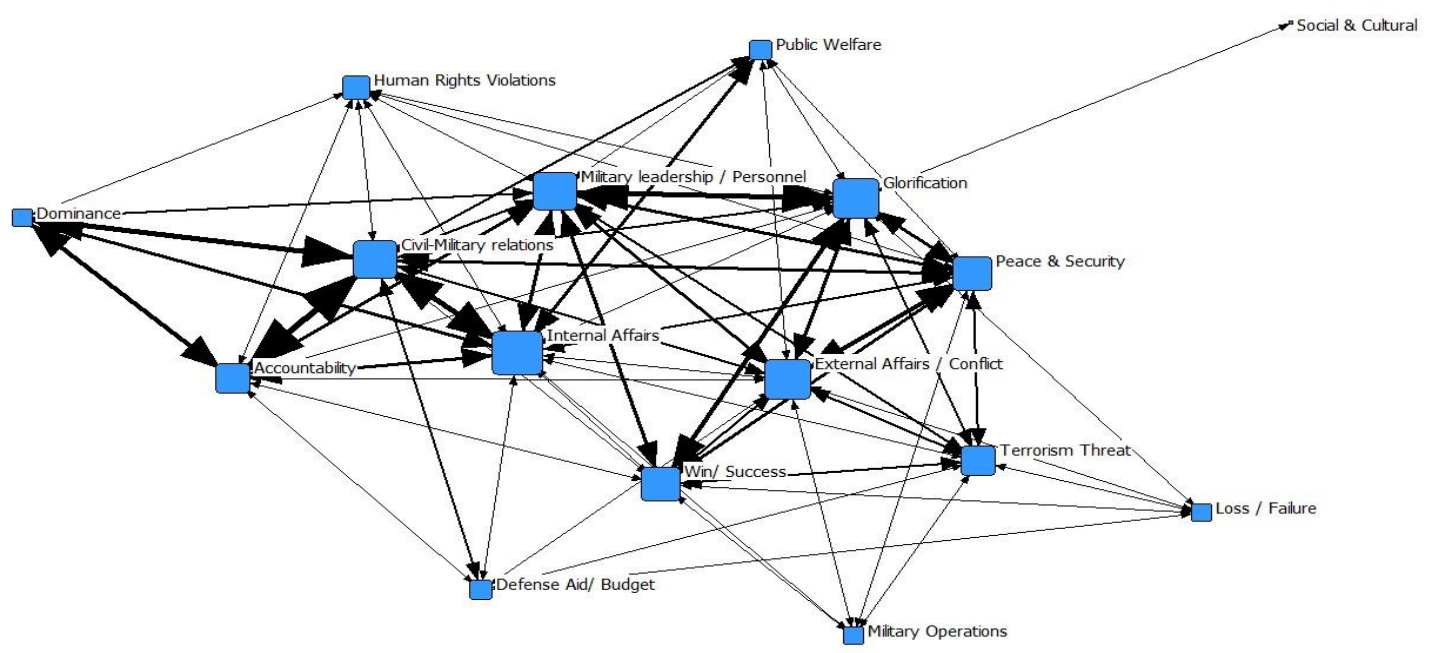

Figure 3: Network Image of Pakistan Army in News Stories of The Dawn ( $\mathrm{N}=262)$

Source: Author's calculation based on the news stories retrieved from online editions of these newspapers

Note: Symbol size represents degree centrality, the closeness of symbols shows relatedness, and thickness of lines indicates the strength interconnectedness of elements.

Network Image of Indian Army in News Stories of Indian Express

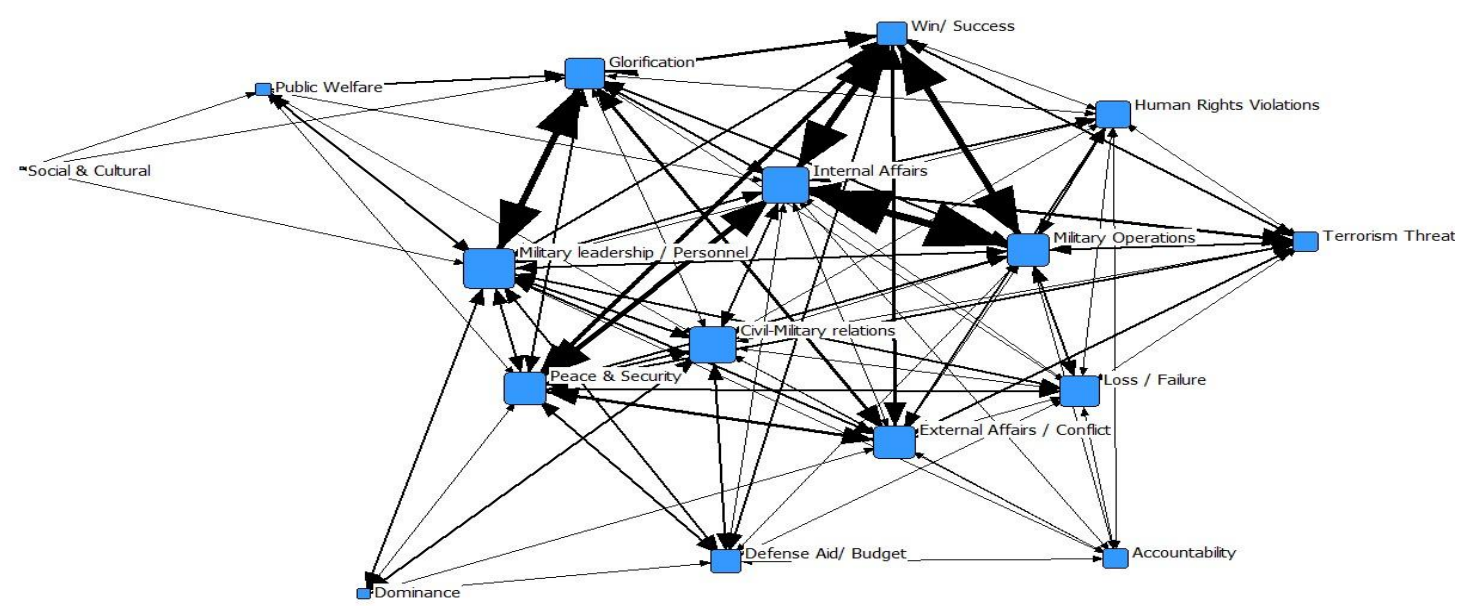

Figure 4: Network Image of Indian Army in News Stories of Indian Express ( $\mathrm{N}=294)$

Source: Author's calculation based on the news stories retrieved from online editions of these newspapers

Network Image of the American Army in News Stories of New York Times 


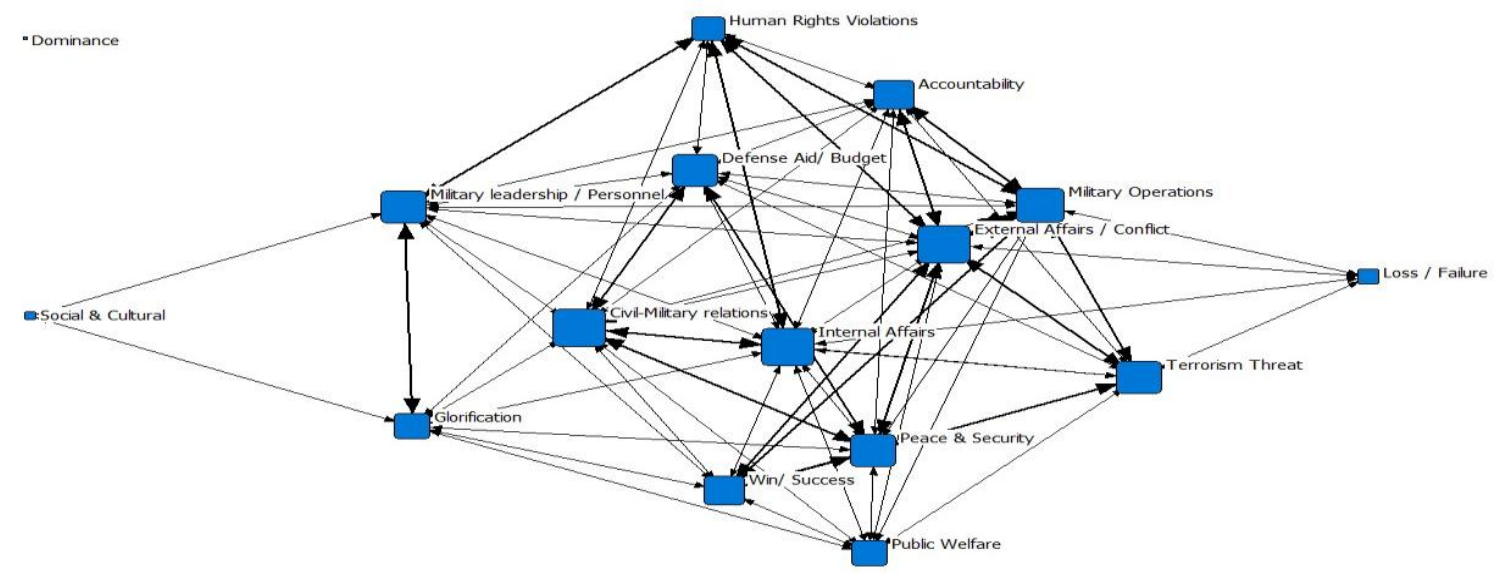

Figure 5: Network Image of the American Army in News Stories of New York Times $(\mathrm{N}=108)$

Source: Author's calculation based on the news stories retrieved from online editions of these newspapers.

Note: Symbol size represents degree centrality, the closeness of symbols shows relatedness, and thickness of lines indicates the strength interconnectedness of elements.

Figure 5 illustrates that the American Army is portrayed positively due to the involvement of external military operations in the New York Times. However, New York Times also linked military operations with accountability. It also highlights civil-military relations affairs and internal peace and security. New York Times also focused on the success of the American Army in attaining peace and security in the country. In this way, the researchers do not find support for the confirmation of H3 that "There would be a significant correlation among the network level agenda of American, Indian and Pakistani press about their armed forces". The researchers found significant differences in the image of Armed forces among The Dawn, Indian Express, and New York Times news coverage. Specifically, the image of the Pakistan Army in The Dawn (Figure 3) is different from the image of the Indian Army (Figure 4) and the image of the American Army (Figure 5). However, both Indian and Pakistani newspapers are the same in glorifying military leadership. Armed forces are considered a key state actor in the internal and external affairs of these nations. Hence, the press of these nations also glorifies the military leadership of their armed forces to create a favorable public image of their armed forces. In a study conducted by Manzoor et al. (2021) on the patterns of print media agendas in the context of war-onterror in Pakistan, it was concluded that "terrorism" was an extensively used word in two leading US newspapers.

\section{CONCLUSION}

The media image of any institution or organization is very vital for influencing the public perception of that institution. Therefore, the media image of armed forces is also very central for maintaining goodwill and practicing war propaganda among the public. In this study, researchers explored the coverage of the Pakistan Army, Indian Army, and the American Army in their national press; The Dawn, Indian Express, and New York Times, respectively. The researchers found that the intermedia agenda-setting is not confirmed in our case due to the dynamic nature of the object and socio-political contexts. Due to the limited scope of this study, researchers do not consider and discuss these factors. Indian Express and New York Times are giving positive coverage to their armed forces.

On the other hand, although The Dawn is also showing positive coverage to armed forces yet it also gives a negative image of the Pakistan Army. The Dawn strongly linked Pakistan Army with civil-military relations (negatively), and the internal affairs of Pakistan. In civil-military relations, it is stressed upon the dominance of the Army (negatively) and its accountability (negatively). However, The Dawn also glorifies the military leadership and the military success and their services and sacrifices for peace and security in the region.

On the other hand, Indian Express heavily focused on the internal military operations and the success of armed forces in these operations for the peace and security of the country positively. Furthermore, it also glorifies the military leadership significantly. Finally, it is concluded that media coverage of armed forces varies in American, Indian, and Pakistani press according to the amount given to the armed forces, the tone of the news stories, attributes of armed forces, and their associations with one another. The New York Times and Indian Express present a highly positive image of their armed forces by glorifying their success and efforts for peace and security. Unfortunately, The Dawn presents a mainly negative image of the Pakistan Army by focusing more on civil-military relations, Army dominance, and accountability. However, Indian Express and The Dawn also have similarities in glorifying military leadership.

\section{RECOMMENDATIONS FOR PAKISTANI MEDIA AND MILITARY}

In line with the empirical findings of the present study, the researchers recommend;

1) Pakistani media should not associate armed forces with internal matters of politics and civil-military relations. 
2) Media regulatory authorities should make a policy for the media not to discuss civil-military relations and negative statements of politicians about armed forces in their news coverage.

3) Indian media and politicians portray the military budget insufficiently and demand to increase it. Unfortunately, in Pakistan, our media and politicians criticize the military budget and demand its accountability. This type of coverage should also be under-covered by the media.

4) Media in Pakistan excites the accountability of ex-military generals. The Army association should not be mentioned in this case. For example, Mr. Raheel Sharif should mention instead of Ex. Army Chief.

5) Pakistan Army should be made a strategy to handle media for not to discuss armed forces in the matters of internal affairs, specifically with relation to civil-military relations.

\section{LIMITATION AND STUDY FORWARD}

The findings of the study should be viewed in the context of the followings limitations. Firstly, due to time constraints, we only selected one newspaper from sample countries. Further studies may include more newspapers. Secondly, findings should be viewed in the geopolitical contexts of sample countries. Because all three countries have different political backgrounds related to armed forces. Pakistan is a country that has observed long terms of military dictatorships. On the other hand, in India and America, the situation is different than that of Pakistan. Thirdly, although efforts were made to reduce human bias, however, human bias error may exist in the findings. Researchers and coders were Pakistani. Therefore, the findings of the study should be viewed in this context.

\section{ACKNOWLEDGEMENT}

I am highly grateful to all of my co-authors who were involved in conducting this qualitative research.

\section{AUTHORS CONTRIBUTION}

Muhammad Riaz Raza conceived the research idea and done with the introduction, literature, and discussion parts. Muhammad Usman Saeed undertook data transcribing and analysis. Zafar Ali has assisted in the research questions, hypothesis development, and data collection. All the contributors have approved the final version of the research paper.

\section{REFERENCES}

1. Adegbola, O. W (2020). Examining determinants of adherence to peace journalism: Empathy, reporting efficacy, and perceived journalistic roles. Media, War \& Conflict. https://doi.org/10.1177/1750635220948548

2. Allan, S., \& Zelizer, B. (2004). Reporting war: Journalism in wartime: Routledge. https://doi.org/10.432 4/9780203497562

3. Anstead, N., \& O'Loughlin, B. (2014). Social media analysis and public opinion: The 2010 UK general election. Journal of Computer-Mediated Communication, 20(2), 204-220. https://doi.org/10.1111/jcc4.12102

4. Ashcroft, M. (2012). The Armed Forces and Society: The Military in Britain through the eyes of Service personnel, employers and the public. Biteback Publishing.

5. Ashraf, M., \& Islam, M. U. (2014). Media Activism and its Impacts on the Psychology of Pakistani Society. ISSRA Papers, 6(3). Available at https://ndu.edu.pk/issra/issra_pub/articles/issra-paper/ISSRA_Papers_Vol 6_IssueI_2014/03-Media-Activism-Muhammad-Ashraf.pdf

6. Awobamise, A., Jarrar, Y., \& Owade, J. (2020). An analysis of media reportage of conflict during the 2007, 2013, and 2017 Kenyan presidential elections: a peace journalism approach. University And Society, 12(2), 184191. Available at https://rus.ucf.edu.cu/index.php/rus/article/view/1506

7. Bali, P. S. (2015). Portrayal of Indian Army in Kashmir Media: An Analytical Study of Local Newspapers. International Journal of Media, Journalism and Mass Communications, 2(1), 51-57. https://doi.org/10.20431/2454-9479.0202005

8. Baran, S., \& Davis, D. (2010). Mass communication theory: Foundations, ferment, and future (6th ed.). Boston: Wadsworth.

9. Best, M. L., Long, W. J., Etherton, J., \& Smyth, T. (2011). Rich digital media as a tool in post-conflict truth and reconciliation. Media, War \& Conflict, 4(3), 231-249. https://doi.org/10.1177/1750635211420628

10. Butts, C. T. (2008). Social network analysis: A methodological introduction. Asian Journal of Social Psychology, 11(1), 13-41. https://doi.org/10.1111/j.1467-839X.2007.00241.x

11. Chaudhry, S., \& Ali, S. (2012). Public Perception about Policies and Practices of ISPR on War on Terror with Special Reference to Military Action in Tribal Areas of Pakistan. Dialogue, 7(2), 103-137.

12. Cheng, Y., \& Chan, C.-M. (2015). The third level of agenda-setting in contemporary China: Tracking descriptions of moral and national education (MNE) in media coverage and people's minds. International Journal of Communication, 9, 1090-1107.

13. Christian, R., Stefan, S., \& Muhammad, I. (2020) Social media in conflicts and crises. Behaviour \& Information Technology, 39(3), 241-251, https://doi.org/10.1080/0144929X.2019.1629025 
14. Daud, B. (2020). Perception of Afghanistan in the Western Media. Available at http://dspace.jgu.e du.in:8080/jspui/bitstream/10739/3705/1/Perception\%20of\%20Afghanistan\%20in\%20the\%20Western\%20Med ia.pdf

15. De Nooy, W., Mrvar, A., \& Batagelj, V. (2011). Exploratory social network analysis with Pajek (2nd ed.). London: Cambridge University Press. https://doi.org/10.1017/CBO9780511996368

16. Datsko, Oleh-Semen. (2020). The Language of War: Framing Enemy Images in Russian Online Media. Helsingin yliopisto Publishers. Available at http://urn.fi/URN:NBN:fi:hulib-202006223286

17. Dawn (2021). Backdoor Channels with PDM. An article published in Daily Dawn. Available at https://www.dawn.com/news/1606205

18. Graber, D. A., \& Smith, J. M. (2005). Political communication faces the 21 st century. Journal of communication, 55(3), 479-507. https://doi.org/10.1111/j.1460-2466.2005.tb02682.x

19. Guo, L. (2012). The application of social network analysis in agenda-setting research: A methodological exploration. Journal of Broadcasting \& Electronic Media, 56(4), 616-631. https://doi.org/10.1080/0883 8151.2012 .732148

20. Guo, L., Vu, H. T., \& McCombs, M. (2012). An expanded perspective on agenda-setting effects: Exploring the third level of agenda-setting. Revista de Comunicación, 11, 51-68.

21. Hadyniak, K. (2015). How Journalism Influenced American Public Opinion During the Vietnam War: A Case Study of the Battle of Ap Bac, The Gulf of Tonkin Incident, The Tet Offensive, and the My Lai Massacre. Honors College. 222. Available at https://digitalcommons.library.umaine.edu/honors/222

22. Happer, C., \& Philo, G. (2013). The role of the media in the construction of public belief and social change. Journal of social and political psychology, 1(1), 321-336. https://doi.org/10.5964/jspp.v1i1.96

23. Heim, K. (2010). The boys on the blogs: Intermedia agenda-setting in the 2008 US presidential campaign. (Doctoral Thesis), University of Missouri--Columbia.

24. Herf, J. (2006). The Jewish Enemy: Nazi propaganda during world war II and the holocaust. Belknap Press of Harvard University Press Cambridge, MA. https://doi.org/10.4159/9780674038592

25. Hines, L. A., Gribble, R., Wessely, S., Dandeker, C., \& Fear, N. T. (2015). Are the armed forces understood and supported by the public? A view from the United Kingdom. Armed Forces \& Society, 41(4), 688-713. https://doi.org/10.1177/0095327X14559975

26. Hussain, S. (2016). Media coverage of Taliban: is peace journalism the solution? Asia Pacific media educator, 26(1), 31-46. https://doi.org/10.1177/1326365X16640340

27. Hussain, S., Siraj, S.A., Mahmood, T. (2019). Evaluating war and peace potential of Pakistani news media: Advancing a peace journalism model. Information Development, 37(1),105-121. https://doi.org/10.1177/02 66666919893416

28. Iftikhar, A., \& Shafiq, S. (2019). The Portrayal of Pak-US Relations in Print Media: An Analysis of War on Terror and Militancy in Pakistan during the Republican and the Democratic Regimes. Global Regional Review (GRR), 4(3), 10-19. https://doi.org/10.31703/grr.2019(IV-III).02

29. Ishaq, N., Saleem, N., \& Mian, H. A. (2018). Media an agent of Peace or war? A study of The Economist, The Herald and Time during American Armed Operations in Pakistan. Pakistan Vision, 19(1), 76-93.

30. Javaid, U. (2015). Operation Zarb-e-Azb: A Successful Initiative to Curtail Terrorism. South Asian Studies. 30(2), 43-58. Available at https://www.researchgate.net/publication/309556452_Operation_Zarb-eAzb_A_Successful_Initiative to_Curtail_Terrorism\#fullTextFileContent

31. Khan, A. (2018). Zarb-e-Azb Operation: Agenda-Setting Role of Newspapers on a National Issue in Pakistan. Journal of Media Studies, 33(2), 41-59. http://pu.edu.pk/images/journal/ICS/PDF/03_V_33_2_2018.pdf

32. Khan, M.K. \& Pratt, C.B. (2020). Strategic communications: The Pakistan military's use of social media against terrorism. Medi. War \& Conflict. https://doi.org/10.1177/1750635220972127

33. Khan, S., \& Akhtar, N. (2016). Operation Zarb-e-Azb: An Analysis of Media Coverage. Strategic Studies, 36(1), 114-127. Available at https://www.jstor.org/stable/e48501859

34. Le, S. (2016). The Relationship Between the Media and the Military. (Master's Thesis). Harvard University, Cambridge, US.

35. Lee, J. H., \& Hahn, K. T. (2014). Factors Influencing the Agenda-Setting Effects of Newspapers on Their Subscribers. Media Economy and Culture, 12(1), 192-233.

36. Manzoor, S., Shahzadi, I., \& Bhatti, A. M. (2021). US Media's Agenda-Setting: Analysis of Editorial Presentations of Pakistan. Pakistan Social Sciences Review, 5(I). https://doi.org/10.35484/pssr.2021(5-I)23

37. Marin, A., \& Wellman, B. (2011). Social Network Analysis: An Introduction. In J. Scott \& P. J. Carrington (Eds.), The Sage Handbook of Social Network Analysis (pp. 11-25). London: Sage Publications Ltd. https://doi.org/10.4135/9781446294413.n2

38. McCombes, M., Lopez-Escobar, E., \& Llamas, J. P. (2006). Setting the agenda of attributes in the 1996 Spanish general election. Journal of communication, 50(2), 77-92. https://doi.org/10.1111/j.1460-2466.2000.tb02842.x

39. McCombs, M. (2005). A look at agenda-setting: Past, present, and future. Journalism Studies, 6(4), $543-557$. https://doi.org/10.1080/14616700500250438

40. McQuail, D. (2010). McQuail's Mass Communication Theory. Washington: DC: Sage publications. 
41. Nišić, V., \& Plavšić, D. (2017). The role of media in the construction of social reality. Sociological Discourse, 4(7), 73-81. https://doi.org/10.7251/SOCEN1407073N

42. Oram, S. S. (1993). Telling the Story: Impact of Military-Media Relations on the Operational Commander: Naval War Coll Newport RI Dept of Operations. https://doi.org/10.21236/ADA264285

43. Parrott, S., Albright, D. L., Dyche, C., \& Steele, H. G. (2018). Hero, Charity Case, and Victim: How US News Media Frame Military Veterans on Twitter. Armed Forces \& Society, 1-21. https://doi.org/10.1177/0095 $327 \times 18784238$

44. Payne, K. (2005). The Media as an Instrument of War. The US Army War College Quarterly: Parameters 35, (1), 81-93. Available at https://press.armywarcollege.edu/parameters/vol35/iss1/10

45. Powell, L. (2014). Glorification of the Military in Popular Culture and the Media. In M. C. Forte (Ed.), Good Intentions: Norms and Practices of Imperial Humanitarianism, 4, 167-184. Canada: Alert Press.

47.Prager, A., \& Hameleers, M. (2021). Disseminating information or advocating peace? Journalists' role perceptions in the face of conflict. Journalism, 22(2), 395-413. https://doi.org/10.1177/1464884918791788

48. Rahman, B. H., \& Eijaz, A. (2014). Pakistani Media as an Agent of Conflict or Conflict Resolution: A Case of Lal Masjid in Urdu and English Dailies. Pakistan Vision, 15(2), 238.

49. Ramić, A. (2015). What media wants from a relationship with the Military? Polemos: časopis za interdisciplinarna istraživanja rata i mira, 18(35), 75-89.

50. Raza, M.R.; Siraj, S.A.; Saeed, U. M. (2020). Image of India and Pakistan in Digital Age: A Comparative Study on Tweets of International News Agencies. International Journal of Distance Education and E-Learning (IJDEEL), $V I(I)$.

51. Rill, L. A., \& Davis, C. B. (2008). Testing the second level of agenda-setting: Effects of news frames on readerassigned attributes of Hezbollah and Israel in the 2006 war in Lebanon. Journalism \& Mass Communication Quarterly, 85(3), 609-624. https://doi.org/10.1177/107769900808500308

52. Scholtz, L. (1998). The media and the military: Allies or adversaries? Scientia Militaria: South African Journal of Military Studies, 28(2), 236-251. https://doi.org/10.5787/28-2-213

53. Seltzer, T., \& Dittmore, S. W. (2009). Down, set, frame: second-level agenda building and the NFL network carriage dispute. International Journal of Sport Communication, 2(3), 340-359. https://doi.org/10. 1123/ijsc.2.3.340

54. Sheafer, T., \& Weimann, G. (2005). Agenda building, agenda-setting, priming, individual voting intentions, and the aggregate results: An analysis of four Israeli elections. Journal of communication, 55(2), 347-365. https://doi.org/10.1111/j.1460-2466.2005.tb02676.x

55. Stern, SO, Tuckett D, Smith RE, Nyman R (2018). Measuring the Influencers in the News Media's Narratives In 2018 IEEE/ACM International Conference on Advances in Social Networks Analysis And Mining (ASONAM), 698-701. https://doi.org/10.1109/ASONAM.2018.8508540

56. Tsfati, Y., \& Cohen, J. (2012). Perceptions of media and media effects: The third-person effect, trust in media and hostile media perceptions. In A. N. Valdivia \& E. Scharrer (Eds.), The international encyclopedia of media studies. New Jersey, US: Blackwell Publishing Ltd. https://doi.org/10.1002/9781444361506.wbiems995

57. United Nations (2020). A New Era of Conflict and Violence. Available at https://www.un.org/en/un75/new-eraconflict-and-violence.

58. Vargo, C. J., Guo, L., McCombs, M., \& Shaw, D. L. (2014). Network issue agendas on Twitter during the 2012 US presidential election. Journal of communication, 64(2), 296-316. https://doi.org/10.1111/jcom.12089

59. Vliegenthart, R., \& Walgrave, S. (2008). The contingency of intermedia agenda-setting: A longitudinal study in Belgium. Journalism \& Mass Communication Quarterly, 85(4), 860-877. https://doi.org/10.1177/10 7769900808500409

60. Vu, H. T., Guo, L., \& McCombs, M. E. (2014). Exploring "the world outside and the pictures in our heads" A network agenda-setting study. Journalism \& Mass Communication Quarterly, 91(4), 669-686. https://doi.org/10.1177/1077699014550090

61. Walgrave, S., Soroka, S., \& Nuytemans, M. (2008). The mass media's political agenda-setting power: A longitudinal analysis of media, parliament, and government in Belgium (1993 to 2000). Comparative Political Studies, 41(6), 814-836. https://doi.org/10.1177/0010414006299098

62. Wasserman, S., \& Faust, K. (1994). Social network analysis: Methods and applications. London: Cambridge university press. https://doi.org/10.1017/CBO9780511815478

63. Wirth, W., Matthes, J., Schemer, C., Wettstein, M., Friemel, T., Hänggli, R., \& Siegert, G. (2010). Agenda building and setting in a referendum campaign: Investigating the flow of arguments among campaigners, the media, and the public. Journalism \& Mass Communication Quarterly, 87(2), 328-345. https://doi.org/10 $.1177 / 107769901008700207$

64. Yang, J. (2008). US, Chinese newspapers frame the Iraq war differently. Newspaper Research Journal, 29(3), 80-93. https://doi.org/10.1177/073953290802900307

65. Yousaf, S. (2015). Representation of Pakistan: A Framing Analysis of the Coverage in the US and Chinese News Media Surrounding Operation Zarb-e-Azb. International Journal of Communication, 9, 3042-3064.

66. Yousaf, Z., Elahi, H., \& Adnan, M. (2018). War and Peace Framing: The Contextual Analysis of Indo-Pak Relations. Strategic Studies, 38(1), 128-144. Available at https://www.jstor.org/stable/48539127 
67. Zhang, C., \& Meadows III, C. W. (2012). International coverage, foreign policy, and national image: Exploring the complexities of media coverage, public opinion, and presidential agenda. International Journal of Communication, 6, 76-95.

\section{Annexure - I: Coding Categories}

\begin{tabular}{|c|c|}
\hline Object/Attribute & Keywords \\
\hline $\begin{array}{l}\text { External Affairs } \\
\text { Conflict }\end{array}$ & $\begin{array}{l}\text { The Afghan War, the Iraq War, North Korea, South Korea Conflict, Israel-Palestine } \\
\text { conflict, etc. }\end{array}$ \\
\hline Civil-Military relations & Government and military relations, Army interference in elections, politics, etc. \\
\hline Military Operations & $\begin{array}{l}\text { Zarb e Azab, Radd-ul-Fassad, Kashmir Indian military operations, military operations in } \\
\text { Afghanistan, Iraq, etc. }\end{array}$ \\
\hline Peace \& Security & Peace dialogues, stability, regional stability, human welfare, human development, etc. \\
\hline $\begin{array}{l}\text { Military leadership / } \\
\text { Personnel }\end{array}$ & $\begin{array}{l}\text { Army chiefs, Intelligence officers, Army soldiers, security forces officers, Commanders, } \\
\text { Generals, Ex. Generals etc. }\end{array}$ \\
\hline Win/ Success & $\begin{array}{l}\text { Successful operations, killings of the other side, scientific experiments of missiles, and } \\
\text { other technology, etc. }\end{array}$ \\
\hline Loss / Failure & $\begin{array}{l}\text { Death of soldiers, damage to the country, or armed forces. Civilian causalities on another } \\
\text { side, technical failure, like air jet crash in pieces of training, etc. }\end{array}$ \\
\hline $\begin{array}{l}\text { Human } \\
\text { Violations }\end{array}$ & $\begin{array}{l}\text { Women killings, children killings, use of pellet guns, human atrocities, women rape, } \\
\text { prisoners' rights violations, damage to social institutions like schools, etc. }\end{array}$ \\
\hline Defence Aid/ Budget & or aid related to defence matters. \\
\hline Accountability & rial of the milit \\
\hline Terrorism Threat & $\begin{array}{l}\text { Security threat, terrorist statements, the threat to the civilians of countries, defence threats, } \\
\text { etc. }\end{array}$ \\
\hline Public Welfare & $\begin{array}{l}\text { Public aid in crises, dengue campaign efforts, aid in floods, aid in a fire, disasters, medical } \\
\text { camps, etc. }\end{array}$ \\
\hline Dominance & $\begin{array}{l}\text { Military hegemony, control on elections, election engineering, selected prime minister, the } \\
\text { military influence on foreign relations, influence on the internal matters of countries. }\end{array}$ \\
\hline Internal Affairs & $\begin{array}{l}\text { Political statements, elections, civil unrest, internal terrorism threats, internal peace and } \\
\text { security issues, internal legal matters, etc. }\end{array}$ \\
\hline Glorification & presentation of cor \\
\hline Social \& Cul & us events, Eids, Holi, Christmas, etc. \\
\hline
\end{tabular}

